\title{
Determination of Trace Deoxyribonucleic Acid by Using Fluorescein Isothiocyanate-Phenosafranine as a Double-Luminescent Phosphorescence Probe
}

\author{
Jia-Ming Liu • Xiao-Mei Huang • Zhen-Bo Liu • Fei-Ming Li • Li-Ping Lin • \\ Xin-Xing Wang • Chang-Qing Lin • Ya-Hong Huang • Zhi-Ming Li $\cdot$ Shao-Qin Lin
}

Received: 25 April 2010 / Accepted: 19 July 2010 / Published online: 28 July 2010

(C) The Author(s) 2010. This article is published with open access at Springerlink.com

\begin{abstract}
Using $\mathrm{Pb}^{2+}$ as ion perturber, phenosafranine (PF) and fluorescein isothiocyanate (FITC) could emit strong and stable room temperature phosphorescence (RTP) signal on the filter paper, respectively. When they were mixed, the phenomenon that the RTP signal of PF and FITC enhanced significantly was found. And $1.12 \mathrm{ag}$ DNA spot ${ }^{-1}$ (sample volume was $0.40 \mu \mathrm{L}$, corresponding concentration was $2.8 \times 10^{-15} \mathrm{~g} \mathrm{~mL}^{-1}$ ) could cause the RTP signal of both PF and FITC to enhance sharply. The content of DNA was proportional to the $\Delta I_{\mathrm{p}}$ of PF and FITC in the system at 634 and $659 \mathrm{~nm}$. Thus, a new solid substrate room temperature phosphorimetry (SSRTP) for the determination of trace DNA was established by using FITC-PF as doubleluminescent phosphorescence probe. The detection limit (LD) of this method calculated by $3 \mathrm{~S}_{\mathrm{b}} / \mathrm{k}$ was $14 \mathrm{zg}$ DNA spot $^{-1}$ for PF and $18 \mathrm{zg}$ DNA spot ${ }^{-1}$ for FITC, respectively, showing high sensitivity. It has been applied to the
\end{abstract}

J.-M. Liu $(\bowtie) \cdot$ X.-M. Huang $•$ F.-M. Li • L.-P. Lin •

X.-X. Wang · Y.-H. Huang

Department of Chemistry and Environmental Science,

Zhangzhou Normal College,

Zhangzhou 363000, People's Republic of China

e-mail: zzsyliujiaming@163.com

X.-M. Huang · C.-Q. Lin · Z.-M. Li

Department of Food and Biological Engineering,

Zhangzhou Institute of Technology,

Zhangzhou 363000, People's Republic of China

Z.-B. Liu

The Third Hospital of Xiamen,

Xiamen 361100, People's Republic of China

S.-Q. Lin

Department of Biochemistry, Fujian Education College,

Fuzhou 350001, China determination of trace DNA in practical samples and the analysis results were in accordance with those of fluorescence probe. The reaction mechanism of SSRTP for the determination of trace DNA was also discussed.

Keywords Deoxyribonucleic acid · Phenosafranine . Fluorescein isothiocyanate - Double-luminescent phosphorescence probe

\section{Introduction}

DNA is not only the basic genetic material of all living beings, but also the main component of chromosomes [1], and it has close relationship with life activities and all kinds of metabolism [2]. Obviously, the determination of DNA content has an important significance [3]. With the development of science and technology, many new methods for the determination of DNA content emerged [4], such as spectrophotometry (LD: $4.0 \times 10^{-9} \mathrm{~g} \mathrm{~mL}^{-1}$ ) [5], fluorimetry (LD: $2.7 \times 10^{-8} \mathrm{~g} \mathrm{~mL}^{-1}$ ) [6], near-infrared fluorescence probe method (LD: $6.4 \times 10^{-8} \mathrm{~g} \mathrm{~mL}^{-1}$ ) [7], resonance light scattering spectroscopy (LD: $1.9 \times$ $10^{-8} \mathrm{~g} \mathrm{~mL}^{-1}$ ) [8], CdTe / CdS core-shell quantum dot fluorescent probe (LD: $2.0 \times 10^{-8} \mathrm{~g} \mathrm{~mL}^{-1}$ ) [9], CdS fluorescence probe method (LD: $1.8 \times 10^{-8} \mathrm{~g} \mathrm{~mL}^{-1}$ ) [10], Morin $\cdot \mathrm{SiO}_{2}$ phosphorescent probe method (LD: $1.5 \times$ $10^{-12} \mathrm{~g} \mathrm{~mL}^{-1}$ ) [11], polymerase chain reaction (PCR) technique [12] and so on. Recently, phosphorescent probes have become efficient tools which can explore the nature of micro-environment or biological macromolecules in organic medium (like configurational changes of nucleic acid and protein) and the reaction mechanism between them and drugs [13]. Phosphorescence has higher sensitivity, and biological molecules have no RTP emission in the near- 
Fig. 1 Phosphorescence spectra of FITC-PF system (Cuvers 1-9 were emission spectra)

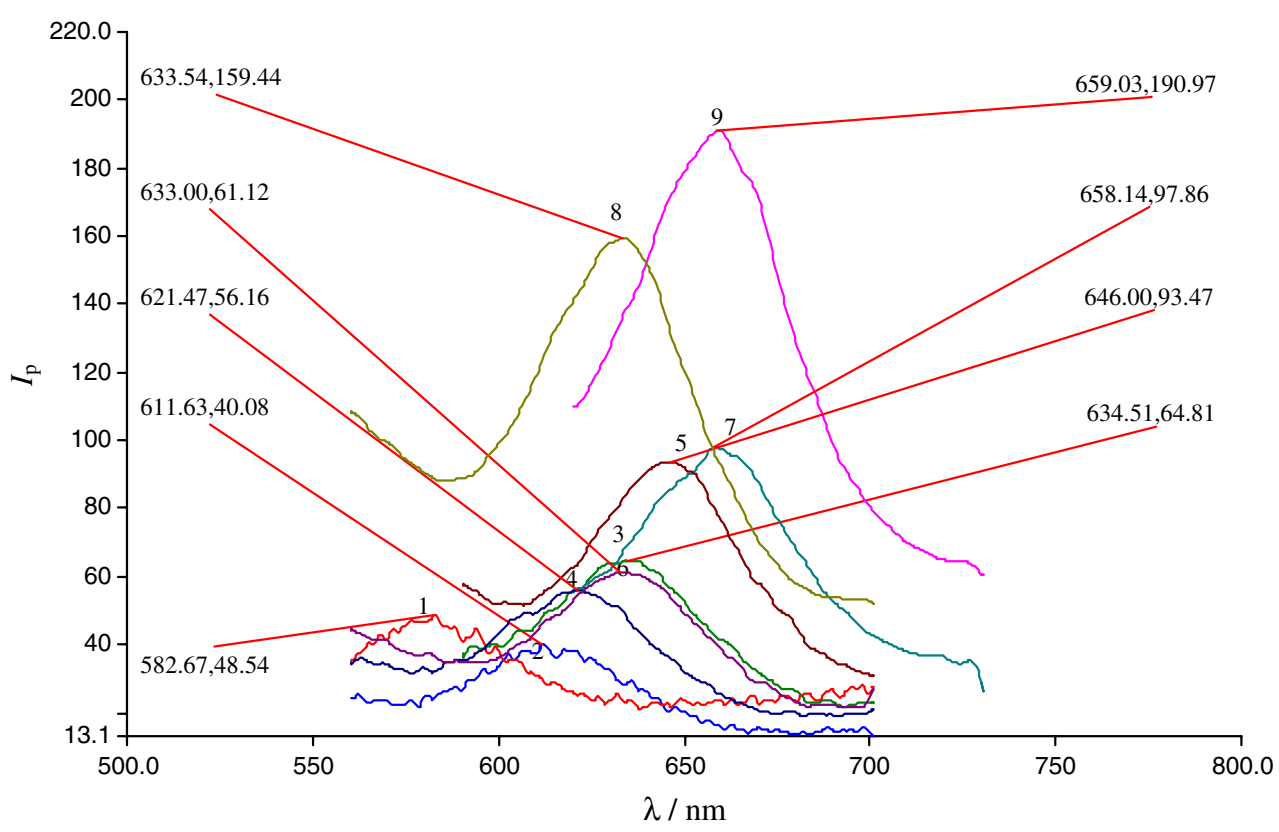

infrared long-wave region. Therefore, the quest and synthesis of a probe which can emit RTP in the longwave region, to eliminate self-interference of biological molecules and to promote selectivity of RTP probe, has special significance to the study of biological molecules, especially, of the concentration and configurational changes of DNA. At the same time, it has a mutual complementation and verification with nucleic acid fluorescent probe [14]. In this paper, we developed a new double-luminescent phosphorescence probe which could emit strong and stable RTP in the long-wave region to further enhance the sensitivity, selectivity and flexibility of SSRTP for the determination of ultra-trace DNA and the research of life science.

In this experiment, we found that FITC-PF could interact with DNA, which resulted in the dramatical enhancement of RTP signal on filter solid substrate, and showed the superior characteristics of a doubleluminescent phosphorescence probe. The optimal condi- tions, analytical parameters, selectivity and the application of SSRTP for the determination of DNA were discussed using FITC-PF as a double-luminescent phosphorescence probe. Compared with a single-luminescent phosphorescence probe [11], the RTP signal of FITC or PF in FITC$\mathrm{PF}$ double-luminescent phosphorescence probe could be used to determine DNA, which not only enhanced the flexibility of SSRTP, but also provided a sensitive, accurate and reliable analytical method to determine trace DNA in biological samples and promoted life science research.

\section{Experimental}

Apparatus and Reagents

A LS-55 luminescence spectrophotometer with a solid surface analysis apparatus (Perkin Elmer Corporation of
Table 1 The RTP characteristics of FITC-PF doubleluminescent phosphorescence probe $\left(\Delta I_{\mathrm{p}}=I_{\mathrm{p}}-I_{\mathrm{p} 0}, I_{\mathrm{p} 0}\right.$ was the RTP intensity of reagent blank, $I_{\mathrm{p}}$ was the RTP intensity of the emission spectra)

\begin{tabular}{|c|c|c|c|c|c|}
\hline System & $\lambda_{\mathrm{em}}(\mathrm{nm})$ & $I_{\mathrm{p}}$ & $\Delta I_{\mathrm{p}}$ & $\Delta \lambda_{\mathrm{em}}$ & Measuring signal \\
\hline 1. Paper & 582.7 & 48.5 & & & \\
\hline 2. $1+0.15 \mathrm{~mL} \mathrm{PF}$ & 611.6 & 40.1 & & & \\
\hline $3.1+1.50 \mathrm{~mL}$ FITC & 634.5 & 64.8 & & & \\
\hline 4. $1+0.15 \mathrm{~mL} \mathrm{PF}+1.50 \mathrm{~mL}$ FITC & 621.5 & 56.2 & 16.1 & 9.9 & $\mathrm{PF}$ \\
\hline 5. $1+0.15 \mathrm{~mL} \mathrm{PF}+1.50 \mathrm{~mL} \mathrm{FITC}$ & 646.0 & 93.5 & 28.7 & 11.5 & FITC \\
\hline 6. $4+1.0$ fg DNA & 633.0 & 61.1 & 4.9 & 11.5 & $\mathrm{PF}$ \\
\hline 7. $5+1.0$ fg DNA & 658.1 & 97.9 & 4.4 & 12.1 & FITC \\
\hline 8. $4+70.0$ fg DNA & 633.5 & 159.4 & 103.2 & 12.1 & $\mathrm{PF}$ \\
\hline 9. $5+70.0$ fg DNA & 659.0 & 180.0 & 86.5 & 13.0 & FITC \\
\hline
\end{tabular}


Table 2 The determination conditions

\begin{tabular}{|c|c|c|c|}
\hline \multicolumn{2}{|l|}{ The measurement condition } & \multirow{2}{*}{$\begin{array}{l}\text { The } \Delta I_{\mathrm{p}} \text { of FITC-PF-DNA system } \\
10.9,21.8,32.4,41.6,42.7,42.6\end{array}$} & \multirow{2}{*}{$\frac{\text { Optimum }}{3.0 \times 10^{-6} \mathrm{~mol} \mathrm{~L}^{-1}}$} \\
\hline $\begin{array}{l}\mathrm{PF} \\
\left.(\mathrm{mol} \mathrm{L})^{-1}\right) \\
(\mathrm{mL})\end{array}$ & $\begin{array}{l}6.0 \times 10^{-9}, 6.0 \times 10^{-8}, 3.0 \times 10^{-7} \\
6.0 \times 10^{-7}, 3.0 \times 10^{-6}, 6.0 \times 10^{-6} \\
0.050,0.10,0.15,0.50,1.0\end{array}$ & & \\
\hline $\begin{array}{l}\text { FITC } \\
\left(\mathrm{mol} \mathrm{L}^{-1}\right) \\
(\mathrm{mL})\end{array}$ & $\begin{array}{l}1.2 \times 10^{-7}, 2.4 \times 10^{-7}, 3.6 \times 10^{-7} \\
1.2 \times 10^{-6}, 2.4 \times 10^{-6}, 3.0 \times 10^{-6} \\
0.40,0.60,0.80,1.00,1.50,2.00\end{array}$ & $\begin{array}{l}20.6,27.7,32.6,34.8,35.7,35.6 \\
20.1,25.7,30.1,32.3,35.6,35.5\end{array}$ & $\begin{array}{l}2.4 \times 10^{-6} \mathrm{~mol} \mathrm{~L}^{-1} \\
1.50 \mathrm{~mL}\end{array}$ \\
\hline $\mathrm{Pb}^{2+}\left(\mathrm{mol} \mathrm{L}^{-1}\right)$ & $0.30,0.50,0.70,1.0,1.20$ & $\begin{array}{l}27.3,34.4,38.6,42.8,42.7 \text { (PF) } \\
24.5,29.3,32.4,35.9,35.8 \text { (FITC) }\end{array}$ & $1.0 \mathrm{~mol} \mathrm{~L}^{-1}$ \\
\hline $\mathrm{pH}$ of the reaction system & $4.10,5.10,5.42,5.76,6.20$ & $\begin{array}{l}33.7,35.8,43.1,43.0,43.1(\mathrm{PF}) \\
31.7,33.4,36.2,36.1,36.2 \text { (FITC) }\end{array}$ & 5.42 \\
\hline Reaction temperature $\left({ }^{\circ} \mathrm{C}\right)$ & $30,40,60,70,80,90$ & $\begin{array}{l}19.3,42.7,33.8,30.1,29.8,27.6 \\
(\mathrm{PF}) \\
18.2,35.6,31.8,29.3,19.6,17.9 \\
\text { (FITC) }\end{array}$ & $40^{\circ} \mathrm{C}$ \\
\hline Desiccation time (min) & $5,10,15,30,40,50$ & $\begin{array}{l}3.2,11.6,42.9,42.9,42.9,40.6(\mathrm{PF}) \\
3.3,10.9,35.6,35.6,35.6,33.2 \\
\text { (FITC) }\end{array}$ & $15 \mathrm{~min}$ \\
\hline Solid substrate & Paper, PAM, NCM, ACM & $\begin{array}{l}42.9,40.1,36.4,23.8(\mathrm{PF}) \\
35.7,33.6,30.6,23.8(\text { FITC })\end{array}$ & Paper \\
\hline Ion perturber & $\mathrm{Pb}^{2+}, \mathrm{I}^{-}, \mathrm{Hg}^{2+}, \mathrm{Ag}^{+}$ & $\begin{array}{l}42.8,40.7,32.4,24.3(\mathrm{PF}) \\
35.7,33.2,29.6,21.5 \text { (FITC) }\end{array}$ & $\mathrm{Pb}^{2+}$ \\
\hline Time of passing $\mathrm{N}_{2}$ (min) & $10,15,20,25,30$ & $\begin{array}{l}42.6,42.4,42.1,43.3,42.2(\mathrm{PF}) \\
35.7,35.1,35.3,35.0,35.6(\mathrm{FITC})\end{array}$ & $\begin{array}{l}\text { Passing } \mathrm{N}_{2} \text { for } 10 \\
\min \end{array}$ \\
\hline $\begin{array}{l}\text { Time of not passing } \mathrm{N}_{2} \\
\text { (min) }\end{array}$ & $10,15,20,25,30$ & $\begin{array}{l}\text { 40.6, 41.4, 42.5, 39.3, } 39.8(\mathrm{PF}) \\
31.7,34.1,35.6,30.4,29.6 \text { (FITC) }\end{array}$ & \\
\hline Standing time (min) & $10,20,30,40,50,60$ & $\begin{array}{l}31.6,42.8,42.9,42.7,42.9,42.8 \\
(\mathrm{PF}) \\
27.9,35.6,35.4,35.6,35.7,35.6 \\
\text { (FITC) }\end{array}$ & $20-60 \min$ \\
\hline
\end{tabular}

American, main parameters are: Ex. Slit: 10 nm; Em. Slit: $10 \mathrm{~nm}$; scan speed: $1,500 \mathrm{~nm} \mathrm{~min}^{-1}$ ), an AE240 electronic analytical balance (Mettler-Toledo Instruments Company Limited), infrared spectrophotometer (Necolet-360 Nicolet Company, USA) and a $0.50-\mu \mathrm{L}( \pm 0.010 \mu \mathrm{L})$ flat head micro-injector (Shanghai Medical Laser Instrument Plant) were used.

CT-DNA working solution (Sigma Company): $1.0 \mathrm{mg} \mathrm{mL}{ }^{-1}$ stock solution was prepared with water and placed at $4^{\circ} \mathrm{C}$ in the refrigerator for use; working solution: diluted $1.0 \mathrm{mg} \mathrm{mL}^{-1}$ stock solution to 10.00 and 1.00 (fg $\mathrm{mL}^{-1}$ ) gradually with water; $1.0 \times 10^{-4} \mathrm{~mol} \mathrm{~L}^{-1} \mathrm{PF}$ solution; $1.0 \times 10^{-4}$ mol L ${ }^{-1}$ FITC solution. All reagents were A.R. grade except that DNA was biological reagent. The water used was thrice-distilled water.

Filter paper, PAM, acetic cellulose membrane (ACM) and nitric cellulose membrane (NCM) were purchased from Luqiaosijia Biochemical Plastic Plant. They were cut into $\operatorname{discs}(\Phi=15 \mathrm{~mm})$ and a ring indentation $(\Phi=4.0 \mathrm{~mm})$ was made at the center of each sheet with a standard pinhole plotter for use.

\section{Experimental Method}

To a 25-mL colorimetric tube, a certain amount of DNA, $1.50 \mathrm{~mL}$ of $4.0 \times 10^{-5} \mathrm{~mol} \mathrm{~L}^{-1}$ FITC and $0.15 \mathrm{~mL}$ of $5.0 \times$ $10^{-4}$ mol L ${ }^{-1} \mathrm{PF}$ were added and diluted with water, and finally mixed homogeneously. The tube was kept at $40^{\circ} \mathrm{C}$ for $15 \mathrm{~min}$, and then cooled by flowing water for $5 \mathrm{~min}$. $0.40 \mu \mathrm{L}$ of different concentrations of DNA and blank solution were suspended onto the center of the paper by a $0.50-\mu \mathrm{L}$ micro-injection, and then dried at $90 \pm 1^{\circ} \mathrm{C}$ for $2 \mathrm{~min}$. Then it was immersed in $1.0 \mathrm{~mol} \mathrm{~L}^{-1} \mathrm{~Pb}(\mathrm{Ac})_{2}$ solution for $10 \mathrm{~s}$, and dried at $90 \pm 1^{\circ} \mathrm{C}$ for $2 \mathrm{~min}$. The phosphorescence intensity of test solution $\left(I \mathrm{p}_{1}\right)$ and reagent blank $\left(I \mathrm{p}_{0}\right)$ were directly measured at $\lambda_{\mathrm{em}}^{\max }=633.5 \mathrm{~nm}$ $(\mathrm{PF})$ or $\lambda_{\mathrm{em}}{ }^{\max }=659.0 \mathrm{~nm}(\mathrm{FITC})$. Then $\Delta I \mathrm{p}\left(=I \mathrm{p}_{1}-I \mathrm{p}_{0}\right)$ was calculated. 
Table 3 Effects of coexistences (1.2 fg DNA mL ${ }^{-1}, 1.2 \mathrm{fg}$ DNA mL $\mathrm{m}^{-1}-\mathrm{X} \mu \mathrm{g} \mathrm{mL} \mathrm{m}^{-1}$ coexistences (ions) were determined by the experimental method for 6 parallel determination, respectively, and the Er was calculated)

\begin{tabular}{|c|c|c|c|c|}
\hline \multicolumn{3}{|l|}{ This method } & \multirow{2}{*}{$\begin{array}{l}\text { Ref.[10] } \\
\text { The allowed concentration }\left(\mu \mathrm{gmL}^{-1}\right)\end{array}$} & \multirow{2}{*}{$\begin{array}{l}\text { Ref.[11] } \\
\text { The allowed concentration }\left(\mu \mathrm{gmL}^{-1}\right.\end{array}$} \\
\hline Coexistent ions & The allowed concentration $\left(\mu \mathrm{gmL}^{-1}\right)$ & $\operatorname{Er}(\%)$ & & \\
\hline Glysin & 90 & -2.4 & 8.0 & 72 \\
\hline Lysin & 75 & 3.5 & 6.0 & 65 \\
\hline Arginine & 70 & 3.6 & 5.0 & 57 \\
\hline Yeast RNA & 15 & -4.5 & 3.0 & 4.5 \\
\hline $\mathrm{Ca}^{2+}$ & 15 & 4.4 & 4.0 & 4.8 \\
\hline $\mathrm{Fe}^{3+}$ & 20 & -4.6 & 2.8 & 11 \\
\hline $\mathrm{Fe}^{2+}$ & 20 & 4.8 & 2.8 & 9 \\
\hline $\mathrm{Co}^{2+}$ & 25 & -2.8 & 6.0 & 12 \\
\hline $\mathrm{Mn}^{2+}$ & 30 & 4.5 & 4.0 & 20 \\
\hline $\mathrm{Cr}^{3+}$ & 20 & -4.7 & & 10 \\
\hline Isoleucine & 70 & 3.3 & 5.5 & 57 \\
\hline Citric acid & 30 & 4.4 & 4.5 & 15 \\
\hline Glucose & 60 & -3.9 & 10 & 48 \\
\hline $\mathrm{Zn}^{2+}$ & 70 & 3.7 & 2.8 & 52 \\
\hline $\mathrm{Mg}^{2+}$ & 90 & 2.6 & 4.8 & 72 \\
\hline $\mathrm{Cu}^{2+}$ & 20 & 4.5 & 1.6 & 10 \\
\hline $\mathrm{K}^{+}$ & 100 & -2.3 & & 80 \\
\hline $\mathrm{NO}_{3}{ }^{-}$ & 50 & 4.2 & & 32 \\
\hline $\mathrm{NO}_{2}^{-}$ & 50 & 4.1 & & 28 \\
\hline $\mathrm{PO}_{4}{ }^{3-}$ & 60 & 3.8 & & 40 \\
\hline $\mathrm{CO}_{3}^{2-}-$ & 60 & -4.1 & & 42 \\
\hline $\mathrm{Br}^{-}$ & 70 & 3.4 & & 50 \\
\hline$\beta$-Cyclodextrin & 10 & 4.8 & & 6.5 \\
\hline Sucrose & 10 & 5.0 & & 3.6 \\
\hline $\mathrm{SO}_{4}{ }^{2-}$ & 60 & 3.8 & & 40 \\
\hline $\mathrm{SO}_{3}{ }^{2-}$ & 50 & 3.7 & & 30 \\
\hline $\mathrm{S}_{2} \mathrm{O}_{3}{ }^{2-}$ & 40 & -4.4 & & 25 \\
\hline $\mathrm{S}^{2-}$ & 30 & 4.5 & & 20 \\
\hline $\mathrm{Cl}^{-}$ & 100 & 2.1 & & 80 \\
\hline $\mathrm{Ac}^{-}$ & 80 & -3.0 & & 60 \\
\hline BSA & 50 & 4.3 & & 30 \\
\hline
\end{tabular}

Infrared Spectra Analysis of FITC, PF and FITC-PF

To a $25-\mathrm{mL}$ colorimetric tube, $15.0 \mathrm{~mL}$ of $4.0 \times$ $10^{-5} \mathrm{~mol} \mathrm{~L}^{-1}$ FITC and $1.5 \mathrm{~mL}$ of $5.0 \times 10^{-4} \mathrm{~mol} \mathrm{~L}^{-1} \mathrm{PF}$ were added and diluted with water, and finally mixed homogeneously. The tube was kept at $40^{\circ} \mathrm{C}$ for $15 \mathrm{~min}$, and then cooled by flowing water for $5 \mathrm{~min}$. FITC-PF (salmon pink spot, $R_{\mathrm{f}}=0.43$ ) was obtained by layer chromatography (chloroform : methanol : acetic acid= 250: $25: 1$ ). Infrared spectra of FITC, PF and FITC-PF were scanned after the sample preparation by pressed disc method with $\mathrm{KBr}$.

\section{Results and Discussion}

Phosphorescence Spectra of the FITC-PF System

The phosphorescence spectra of the FITC-PF system were scanned by the experimental method (Fig. 1, Table 1). Using $\mathrm{Pb}^{2+}$ as the ion perturber, $\mathrm{PF}$ and FITC could emit strong and stable RTP signal on filter paper solid substrate. And their $\lambda_{\mathrm{em}}{ }^{\max }$ were $611.6 \mathrm{~nm}$ and $634.5 \mathrm{~nm}, I_{\mathrm{p}}$ values were 40.1 and 64.8 , respectively. However, the RTP signals of PF and the FITC in the FITC-PF system were significantly enhanced, their $\lambda_{\mathrm{em}}{ }^{\max }$ were $621.5 \mathrm{~nm}$ and 
Table 4 Analysis results of DNA in honey $(n=6)$

\begin{tabular}{|c|c|c|c|c|c|c|c|c|}
\hline Samples & $\begin{array}{l}\text { Measured value } \\
\left(\text { ng } \mathrm{mL}^{-1}\right)\end{array}$ & $\begin{array}{l}\text { Adding amount } \\
\left(\mathrm{ng} \mathrm{mL}^{-1}\right)\end{array}$ & $\begin{array}{l}\text { Recovery } \\
\left(\text { ng mL } L^{-1}\right)\end{array}$ & $\begin{array}{l}\text { Recovery } \\
\text { rate }(\%)\end{array}$ & RSD (\%) & $\begin{array}{l}\text { Ref.[16] } \\
\left(\text { ng mL }^{-1}\right)\end{array}$ & RE (\%) & $\begin{array}{l}\text { Working } \\
\text { wavelength }\end{array}$ \\
\hline \multirow[t]{2}{*}{ Honey A } & 0.114 & 0.010 & 0.0099 & 99.0 & 3.7 & 0.111 & 2.7 & $634 \mathrm{~nm}(\mathrm{PF})$ \\
\hline & 0.118 & 0.010 & 0.010 & 100.0 & 4.3 & 0.115 & 2.6 & $659 \mathrm{~nm}$ (FITC) \\
\hline \multirow[t]{2}{*}{ Honey B } & 0.128 & 0.010 & 0.010 & 100.0 & 3.6 & 0.130 & -1.5 & 634 nm (PF) \\
\hline & 0.134 & 0.010 & 0.0099 & 99.0 & 4.5 & 0.137 & -2.2 & $659 \mathrm{~nm}$ (FITC) \\
\hline \multirow[t]{2}{*}{ Honey C } & 0.135 & 0.010 & 0.0098 & 98.4 & 4.1 & 0.138 & -2.2 & $634 \mathrm{~nm}(\mathrm{PF})$ \\
\hline & 0.140 & 0.010 & 0.010 & 99.7 & 3.5 & 0.144 & -2.8 & $659 \mathrm{~nm}$ (FITC) \\
\hline \multirow[t]{2}{*}{ Honey D } & 0.151 & 0.010 & 0.0099 & 99.6 & 4.3 & 0.153 & -1.3 & 634 nm (PF) \\
\hline & 0.156 & 0.010 & 0.010 & 100.2 & 4.1 & 0.159 & -1.9 & $659 \mathrm{~nm}$ (FITC) \\
\hline \multirow[t]{2}{*}{ Honey E } & 0.163 & 0.010 & 0.0099 & 99.3 & 3.9 & 0.161 & 1.2 & $634 \mathrm{~nm}(\mathrm{PF})$ \\
\hline & 0.167 & 0.010 & 0.010 & 100.2 & 3.6 & 0.164 & 1.8 & $659 \mathrm{~nm}$ (FITC) \\
\hline \multirow[t]{2}{*}{ Honey F } & 0.180 & 0.010 & 0.0099 & 98.9 & 3.2 & 0.178 & 1.1 & $634 \mathrm{~nm}(\mathrm{PF})$ \\
\hline & 0.183 & 0.010 & 0.0099 & 99.1 & 3.7 & 0.180 & 1.7 & $659 \mathrm{~nm}($ FITC) \\
\hline
\end{tabular}

$646.0 \mathrm{~nm}, I_{\mathrm{p}}$ values were 56.2 and 93.5, respectively, namely their $\lambda_{\mathrm{em}}{ }^{\max }$ red shifted for $9.9 \mathrm{~nm}$ and $11.5 \mathrm{~nm}$, which prompted that there was a new compound formed. When 70.0 fg DNA was added, the RTP signal of PF and FITC in FITC-PF system were dramatically increased, their $\lambda_{\text {em }}{ }^{\max }$ were $633.5 \mathrm{~nm}$ and $659.0 \mathrm{~nm}, I_{\mathrm{p}}$ values were 103.2 and 86.5, with the $\lambda_{\mathrm{em}}{ }^{\max }$ red shifting for $12.1 \mathrm{~nm}$ and $13.0 \mathrm{~nm}$, respectively. The reason might be that $\mathrm{PF}$ and FITC interacted with DNA to generate new materials, respectively. According to the relationship between RTP signal and DNA content, the possibility of SSRTP for the determination of DNA content was revealed using FITC-PF as a double-luminescent phosphorescence probe.

\section{The Optimal Determination Conditions}

For the system containing 0.48 ag DNA spot ${ }^{-1}$, the effects of the concentration and volume of PF, FITC, acidity of reaction, temperature and time of reaction, solid substrate, standing time, the species of ion perturber and concentrations of $\mathrm{Pb}^{2+}$ on the $\Delta / \mathrm{p}$ of the system were tested, respectively (Table 2). The results showed that the $\Delta I \mathrm{p}$ of the system reached the maximum when $0.15 \mathrm{~mL}$ of $3.0 \times$ $10^{-6} \mathrm{~mol} \mathrm{~L}^{-1} \mathrm{PF} 、 1.50 \mathrm{~mL}$ of $2.4 \times 10^{-6} \mathrm{~mol} \mathrm{~L}^{-1} \mathrm{PF}$ were used, the $\mathrm{pH}$ of reaction system was 5.42 , the reaction temperature was $40^{\circ} \mathrm{C}$ and the time was $15 \mathrm{~min}$, time of passing $\mathrm{N}_{2}$ was $10 \mathrm{~min}$, paper as solid substrate as well as $1.0 \mathrm{~mol} \mathrm{~L}^{-1} \mathrm{~Pb}^{2+}$ was used.

Working Curve, Linear Range, LD and the Limit of Quantification (LOQ)

Under the optimal determination conditions, the content of DNA ranging from $0.0080 \mathrm{ag}$ spot $^{-1}$ to $1.12 \mathrm{ag} \mathrm{spot}^{-1}$ (corresponding concentration: $0.020-2.8 \mathrm{fg} \mathrm{mL}^{-1}$, sample volume: $0.40 \mu \mathrm{L}$ ) had good linear relationship with the $\Delta I_{\mathrm{p}}$ of the system (When the content of DNA were 0, 0.008, $0.16,0.48,0.80$, and $1.12 \mathrm{ag} \mathrm{spot}^{-1}$, the $\Delta I_{\mathrm{p}}$ of the system were $0,4.9,14.3,42.9,71.4,103.2$ (for PF) and 0, 4.4, $11.9,35.7,59.5,86.5$ (for FITC), respectively.). When a FITC-PF double-luminescent phosphorescence probe was used to determine DNA content, the regression equations of working curve were $\Delta I_{\mathrm{p}}=1.600+89.06 \mathrm{~m}_{\mathrm{DNA}}\left(\mathrm{ag} \operatorname{spot}^{-1}\right)$ and $\Delta I_{\mathrm{p}}=1.391+74.39 \mathrm{~m}_{\mathrm{DNA}}\left(\mathrm{ag}\right.$ spot $\left.^{-1}\right)$; correlation coefficients (r) were 0.9987 and 0.9984 ; RSDs were 1.2$4.5 \%$ and $1.5 \%-3.4 \%$ (measured 0.020 and $1.12 \mathrm{ag} \mathrm{spot}^{-1}$ DNA for 7 parallel determination to calculate the RSD); LD were 2.8 ag spot $^{-1}$ and $3.3 \mathrm{ag}$ spot $^{-1}$ (measured reagent

Fig. 2 Reaction between $P F$ and FITC

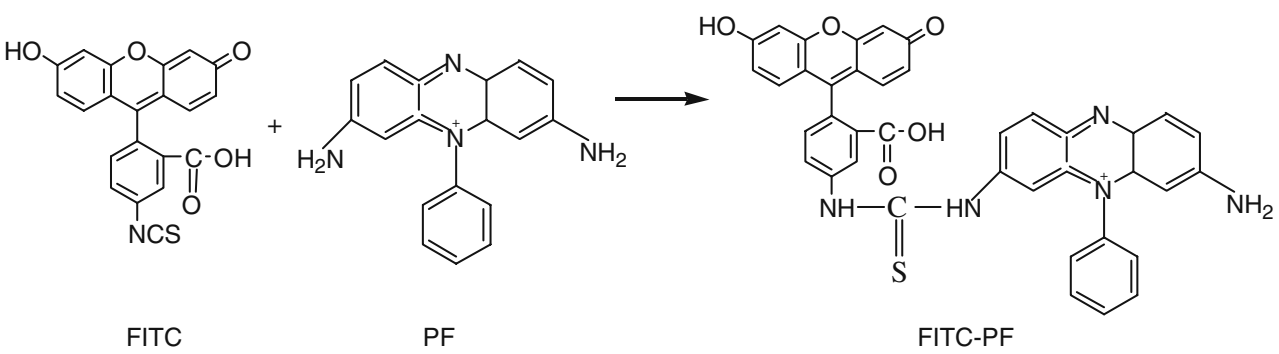


Table 5 Infrared spectrum data of FITC, PF and FITC-PF ( $v$ is stretching vibration; $\delta$ is in-plane bending vibration and $w$ is out-plane bending vibration)

\begin{tabular}{|c|c|c|c|c|c|c|c|c|c|c|c|}
\hline \multirow[t]{2}{*}{ Sample } & \multirow{2}{*}{$\begin{array}{l}-\mathrm{OH} \\
\left(\mathrm{cm}^{-1}\right)\end{array}$} & \multirow{2}{*}{$\begin{array}{l}-\mathrm{C}=\mathrm{O} \\
\left(\mathrm{cm}^{-1}\right)\end{array}$} & \multirow{2}{*}{$\begin{array}{l}-\mathrm{NCS} \\
\left(\mathrm{cm}^{-1}\right)\end{array}$} & \multirow{2}{*}{$\begin{array}{l}-\mathrm{C}_{6} \mathrm{H}_{5} \\
\left(\mathrm{~cm}^{-1}\right)\end{array}$} & \multicolumn{5}{|c|}{ Phenazine ring } & \multirow{2}{*}{$\begin{array}{l}-\mathrm{NH}_{2} \\
\left(\mathrm{~cm}^{-1}\right)\end{array}$} & \multirow{2}{*}{$\begin{array}{l}-\mathrm{N}-\mathrm{CS}-\mathrm{N}- \\
\left(\mathrm{cm}^{-1}\right)\end{array}$} \\
\hline & & & & & $\mathrm{C}=\mathrm{C}\left(\mathrm{cm}^{-1}\right)$ & $\mathrm{C}-\mathrm{N}\left(\mathrm{cm}^{-1}\right)$ & $-\mathrm{C}=\mathrm{N}\left(\mathrm{cm}^{-1}\right)$ & $\mathrm{CH}\left(\mathrm{cm}^{-1}\right)$ & $\mathrm{CH}\left(\mathrm{cm}^{-1}\right)$ & & \\
\hline FITC & $v: 3,345$ & $v: 1,732$ & $v: 2,050$ & $\begin{array}{l}\text { v: } 1,607 \\
\text { v: } 1,494 \\
\text { v: } 1,439\end{array}$ & $\begin{array}{l}\text { v: } 1,610 \\
\text { v: } 1531\end{array}$ & $v: 1,491$ & & & & & \\
\hline $\mathrm{PF}$ & & & & & & & v: 1,333 & $\begin{array}{l}\delta: 1,073 \\
\delta: 1,016 \\
\delta: 947\end{array}$ & $\begin{array}{l}\text { w: } 876 \\
\text { w: } 831 \\
\text { w: } 801 \\
\text { w: } 747 \\
\text { w: } 698\end{array}$ & $\begin{array}{l}v: 3,321 \\
\vee: 3,177 \\
v: 1,642 \\
\delta: 1,193\end{array}$ & \\
\hline FITC-PF & v: 3,348 & $v: 1,736$ & & $\begin{array}{l}\text { v: } 1,610 \\
\text { v: } 1,498 \\
\text { v: } 1,445\end{array}$ & $\begin{array}{l}v: 1,617 \\
v: 1536\end{array}$ & $v: 1,496$ & $v: 1,338$ & $\begin{array}{l}\delta: 1,079 \\
\delta: 1021 \\
\delta: 952\end{array}$ & $\begin{array}{l}\text { w: } 836 \\
\text { w: } 808 \\
\text { w: } 754 \\
\text { w:704 }\end{array}$ & $\begin{array}{l}v: 3,325 \\
v: 3,182 \\
v: 1,648 \\
\delta: 1,197\end{array}$ & $v: 1,380$ \\
\hline
\end{tabular}

blank for 11 parallel determination, calculated by $3 \mathrm{Sb} / k$ and $\mathrm{Sb}$ were 0.042 and 0.046 , respectively.), LOQ were $9.2 \mathrm{ag}$ $\operatorname{spot}^{-1}$ and $10.9 \mathrm{ag} \mathrm{spot}^{-1}$ (calculated by $10 \mathrm{Sb} / k$ ), respectively. The results showed that this method was of good precision and high sensitivity.

\section{Interference Experiment}

Under the optimal conditions, the DNA content was measured by this method $\left(1.2 \mathrm{fg} \mathrm{mL}^{-1}\right)$ and those in the

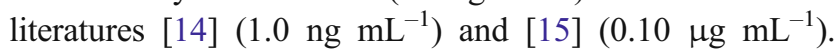

When the relative error (Er) was within $\pm 5 \%$, the maximum allowed concentrations of coexistences are listed in Table 3.

The results showed that the maximum allowed concentrations of coexistences of this method were higher than those of the literatures [10, 11], which indicated high selectivity. And the maximum allowed concentrations of common cations $\left(\mathrm{Mg}^{2+}, \mathrm{K}^{+}, \mathrm{Ca}^{2+}\right)$, which might combine with the phosphate group (P) of DNA [15], were higher with less interference. While the maximum allowed concentrations of $\mathrm{Mn}^{2+}, \mathrm{Cr}^{3+}, \mathrm{Fe}^{3+}, \mathrm{Co}^{2+}$ were lower, the
Fig. 3 Reaction between DNA and FITC-PF

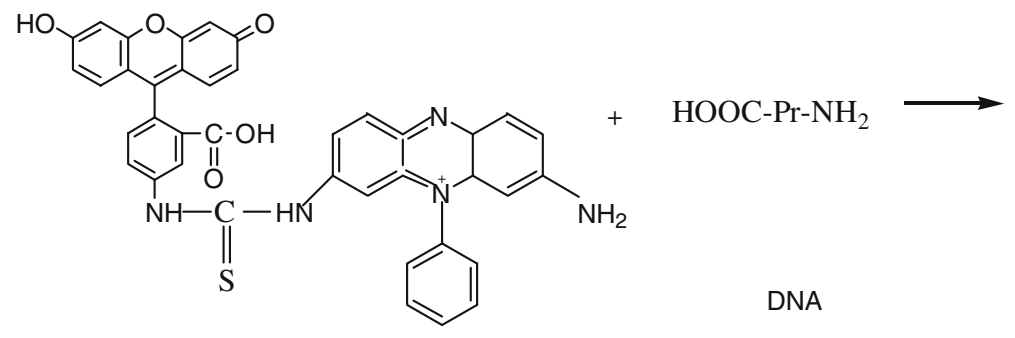<smiles></smiles>

FITC-PF-DNA 
reason might be that they combined with the bases of DNA [15] and destroyed the hydrogen bonds, which led to acute changes in DNA structure. For the reason that the allowed concentrations of interference ions were higher than those in biological body, the interference of this method used to determine biological fluids was less. The allowed concentration of yeast RNA was $4.5 \mathrm{mg} \mathrm{L}^{-1}$, so this method was suitable for the determination of RNA.

\section{Sample Analysis}

$1.0 \mathrm{~g}( \pm 0.10 \mathrm{mg}) \mathrm{A}, \mathrm{B}, \mathrm{C}, \mathrm{D}, \mathrm{E}$ and F nectar were weighed and treated according to the method mentioned in Ref. [16], and diluted to $100 \mathrm{~mL}$ with water; $1.00 \mathrm{~mL}$ test solution were taken and diluted to $100 \mathrm{~mL}$ with water. Taking $1.00 \mathrm{~mL}$ test solution and measuring the DNA content of samples according to the experimental method and that in literature [16]. The results are listed in Table 4.

Seen from Table 4, no matter the working wavelength of FITC or that of PF in FITC-PF double-luminescent phosphorescence probe was used to determine the DNA content in honey A, B, C, D, E, F and G, the recovery rates (\%) were within 99.0-100.2 and 98.4-100.0, RSDs (\%) were in the context of 3.5-4.5 and 3.2-4.3, respectively, which showed that this method was of good flexibility, high accuracy and precision.

\section{Reaction Mechanism}

Using $\mathrm{Pb}^{2+}$ as perturber, both PF and FITC on filter paper solid substrate could emit strong and stable RTP signal after reacting at $40^{\circ} \mathrm{C}$ for $15 \mathrm{~min}$; when they were mixed, the RTP signal of PF and FITC significantly enhanced with the $\lambda_{\mathrm{em}}{ }^{\max }$ red shifting for $9.9 \mathrm{~nm}$ and $11.5 \mathrm{~nm}$, the reason might be that the -NCS [17] in FITC molecules reacted with the $-\mathrm{NH}_{2}$ in $\mathrm{PF}$ molecules to produce new compounds FITC-PF (Fig. 2) which contained -NH-CS-NH- bond:

The infrared spectra of FITC, PF and FITC-PF was scanned in order to discussed the possibility that FITC reacted with PF to form FITC-PF. And the results are listed in Table 5.

The infrared spectra of FITC-PF kept the most characteristic adsorption peak of FITC and PF, but the stretching vibration peak of $-\mathrm{NCS}\left(v: 2,050 \mathrm{~cm}^{-1}\right)$ in the range of 2,150-2,020 $\mathrm{cm}^{-1}$ disappeared and appeared a new stretching vibration peak of $-\mathrm{N}-\mathrm{CS}-\mathrm{N}-\left(\vee: 1,380 \mathrm{~cm}^{-1}\right)$ in the range of $1,430-1,130 \mathrm{~cm}^{-1}$. Thus, it could conclude that the $-\mathrm{NCS}$ of FITC reacted with $-\mathrm{NH}_{2}$ to form the FITC-PF.

When 70.0 fg DNA existed, the RTP signal of PF and FITC in FITC-PF system dramatically increased with the $\lambda_{\mathrm{em}}{ }^{\text {max }}$ red shifting for $12.1 \mathrm{~nm}$ and $13.0 \mathrm{~nm}$, respectively. The reason might be the $-\mathrm{COOH}$ in $\mathrm{H}_{2} \mathrm{~N}-\mathrm{Pr}-\mathrm{COOH}$ (DNA) molecule reacted with the $-\mathrm{NH}_{2}$ in FITC-PF to produce FITC-PF-DNA (Fig. 3).
According to the linear relationship between DNA content and the $\Delta I_{\mathrm{p}}$ of the system, SSRTP can be used to determine DNA content using FITC-PF as a doubleluminescent phosphorescence probe.

\section{Conclusion}

In this paper, FITC-PF double-luminescent phosphorescence probe was developed, a new SSRTP for the determination of trace DNA was estabilished, DNA content in honey was determined by the emission wavelength of FITC and PF in double-luminescent phosphorescence RTP probe, respectively. The flexibility and applicability of SSRTP have been improved, showing broader application prospect. If FITC-PF double-luminescent phosphorescence probe is used to label antibodies and lectins, SSRTP immunization method or SSRTP affinity adsorption method for the determination of trace biological active substances (such as IgG, IgA, IgM, IgE, alkaline phosphatase, alphafetoprotein heterogeneity and so on.) will be established, showing the application prospect of phosphorescence probe.

Acknowledgements This work was supported by Fujian Province Science Foundation (Grant No. 2010J01053, 2009J1017 and 2008J0313) and Fujian Education Office Science and Technology Item Programme (JA08252, JB08262 and JB09278) and Scientific Research Program of Zhangzhou Institute of Technology Foundation (Grant No. ZZY0942, ZZY0952). At the same time, we are very grateful to precious advices raised by the reviewers and the editorial of Journal of Fluorescence.

Open Access This article is distributed under the terms of the Creative Commons Attribution Noncommercial License which permits any noncommercial use, distribution, and reproduction in any medium, provided the original author(s) and source are credited.

\section{References}

1. Li Z, Lai JP, Wu CL, Guo XQ, Zhao YY (2006) Study on the interaction mechanism of DNA and $\mathrm{Tb}^{3+}$ by fluorimetry. $\mathrm{J}$ Xiamen Univ (Nat Sci) 45(1):76-79

2. Luan JM, Zhang XD (2006) Progress of the study on the mode of combination of bioprobes with DNA and of the determination of DNA by photometry. PTCA Part B: Chem Anal 42:964-968

3. Topal MD, Fresco JR (1980) Fluorescence of terbiumion-nucleic acid complexes: a sensitive specific probe for unpaired residues in nucleic acids. Biochem 19(24):5531-5537

4. Ding C, Cantor CR (2004) Quantitative analysis of nucleic acids the last few years of progress. J Biochem Mol Biol 37(1):1210

5. Wei XP, Sun XY (2006) Kinetics spectrophotometric determination of nucleic acid. J Guilin Univ Technol 26(4):562-564

6. Guo LQ, Ye FG, Lin XC, Xie ZH (2006) Determination of nucleic acids using toluidine blue as a fluorescence probe. Spectrosc Spect Anal 26(1):121-124 
7. Hu M, Zhang ZX, Shen GL, Liu YL (2007) Near-infrared fluoresent probe of azure a for the determination of deoxyribonucleic acid. Chin J Anal Chem 35(6):890-892

8. Feng S, Li ZP, Wu QH, Fang Z, Zhang SH (2007) Resonance scattering spectrometric determination of DNA with polyamine as a probe. PTCA (Part B: Chem Anal) 43(7):555-557

9. Xu J, Zhao YS, Wang HM, Wu XG, Cai RX (2006) Application of $\mathrm{CdTe} / \mathrm{CdS}$ core-shell quantum dots synthesized in an aqueous solution as fluorescence probe for the determination of nucleic acids. Chin J Anal Lab 25(4):50-53

10. Wang L, Guo C, Li MG, Xu FG, Zhu CQ, Wang L (2003) Fluorescence quenching method for the determination of nucleic acids with functionalized $\mathrm{CdS}$ nanoparticles as fluorescence probes. Chin J Anal Chem (31):83-86

11. Liu JM, Yang TL, Gao F et al (2006) Determination of DNA by solid substrate room temperature phosphorescence enhancing method based on the morin $\cdot \mathrm{SiO}_{2}$ luminescent nanoparticles-Pd system as a phosphorescence probe. Anal Chim Acta 561: 191-197

12. Chen CF, Ridzon DA, Broomer AJ (2005) Real-time quantification of micro RNAs by stem-loop RT-PCR. Nucleic Acids Res 33 (20): 179

13. Yuan W, Jin WJ, Wei YS et al (1999) Chem J Chin Univ 20:344

14. Feng Q, Li NQ, Jiang YY (1997) Anal Chim Acta 344:97-104

15. Yang P (1991) Introduction of bioinorganic chemistry. Xi'an Communication University Press, pp 275

16. Zhu ZC, Wang J, Zhu HB (2002) Determination of nucleic acids using morin-niobium complex as a fluorescence probe. Chin $\mathrm{J}$ Anal Chem 30(11):1319-1321

17. Liu JM, Liu ZB, He HX et al (2008) Determination of glucose by affinity adsorption solid substrate room temperature phosphorimetry based on triticum vulgare lectin labeled with silicon dioxide nanoparticle containing fluorescein isothiocyanate. Chin J Chem 26(9):1635-1640 